\title{
"Remuneration and reward systems during an economic crisis: case study from Attica region, Greece"
}

Stamatios Ntanos iD https://orcid.org/0000-0001-7718-1223
R http://www.researcherid.com/rid/J-2732-2019
Georgios Sidiropoulos iD https://orcid.org/0000-0003-4305-3893
Evangelia Triantafyllou
Miltiadis Chalikias iD https://orcid.org/0000-0003-1482-0926
Grigorios L. Kyriakopoulos iD https://orcid.org/0000-0003-4875-8534
R http://www.researcherid.com/rid/A-5933-2008

Stamatios Ntanos, Georgios Sidiropoulos, Evangelia Triantafyllou, Miltiadis

ARTICLE INFO Chalikias and Grigorios L. Kyriakopoulos (2020). Remuneration and reward systems during an economic crisis: case study from Attica region, Greece. Problems and Perspectives in Management, 18(2), 261-276. doi:10.21511/ppm.18(2).2020.22

DOI http://dx.doi.org/10.21511/ppm.18(2).2020.22

RELEASED ON

Friday, 19 June 2020

RECEIVED ON

Monday, 06 April 2020

ACCEPTED ON

Thursday, 04 June 2020

\section{(c))EY}

LICENSE

This work is licensed under a Creative Commons Attribution 4.0 International License

JOURNAL "Problems and Perspectives in Management"

ISSN PRINT $1727-7051$

ISSN ONLINE $1810-5467$

PUBLISHER

LLC "Consulting Publishing Company "Business Perspectives"

FOUNDER

LLC "Consulting Publishing Company "Business Perspectives"

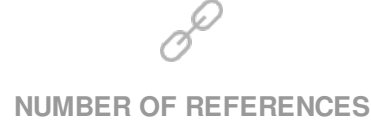

61
NUMBER OF FIGURES

2

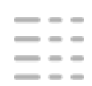

NUMBER OF TABLES

\section{3}

(C) The author(s) 2022. This publication is an open access article. 


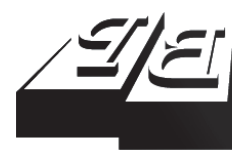

BUSINESS PERSPECTIVES

(2)

LLC "CPC "Business Perspectives" Hryhorii Skovoroda lane, 10, Sumy, 40022, Ukraine www.businessperspectives.org

Received on: $6^{\text {th }}$ of April, 2020 Accepted on: $4^{\text {th }}$ of June, 2020 Published on: $19^{\text {th }}$ of June, 2020

(c) Stamatios Ntanos, Georgios Sidiropoulos, Evangelia Triantafyllou, Miltiadis Chalikias, Grigorios L. Kyriakopoulos, 2020

Stamatios Ntanos, Special and Laboratory Teaching Staff, Department of Business Administration, School of Business, Economics and Social Sciences, University of West Attica, Greece.

Georgios Sidiropoulos, M.Sc. Graduate, Department of Business Administration, School of Business, Economics and Social Sciences, University of West Attica, Greece.

Evangelia Triantafyllou, M.Sc. Graduate, Department of Business Administration, School of Business, Economics and Social Sciences, University of West Attica, Greece.

Miltiadis Chalikias, Associate Professor, Department of Accounting and Finance, School of Business and Economics, University of West Attica, Greece.

Grigorios L. Kyriakopoulos, Dr., Chemical Engineer, Teaching and Research Associate, School of Electrical and Computer Engineering, Electric Power Division, Photometry Laboratory, National Technical University of Athens, Greece. (Corresponding author)
Stamatios Ntanos (Greece), Georgios Sidiropoulos (Greece), Evangelia Triantafyllou (Greece), Miltiadis Chalikias (Greece), Grigorios L. Kyriakopoulos (Greece)

\section{REMUNERATION}

\section{AND REWARD SYSTEMS DURING AN ECONOMIC CRISIS: CASE STUDY FROM ATTICA REGION, GREECE}

\begin{abstract}
This study investigated the structure of employees' remuneration and rewards systems, focusing on medium- and large-sized firms in the region of Attica in Greece during the economic crisis. Data were collected using a structured questionnaire based on relevant literature. A sample of 150 companies filled out a total of 500 questionnaires. The results revealed that medium- and large-sized companies applied various remuneration systems, including the base wage, performance-related bonuses, and a combination of additional non-wage benefits. Greek firms did not avoid wage cut in times of low turnover, although hypotheses testing revealed no relationship between firm size and the use of flexible remuneration systems. However, a positive relationship between the unions' engagement and the use of non-wage cutting strategies was confirmed. Furthermore, a positive correlation between wage rigidity, labor market legislation, and collective agreements for setting minimum wage levels was found. Finally, a hypothesis test regarding the association between the firm, the business sector, and wages cut over the last seven years was accepted. The study concludes that wages cut should be the final choice by firms since remuneration is a source to satisfy, engage, and attract employees.
\end{abstract}

\section{Keywords}

economic crisis, labor costs, remuneration, rewards systems, wage rigidity

\section{JEL Classification E24, M52, M54}

\section{INTRODUCTION}

The economic crisis in Greece has been the most severe in its modern history due to exogenous and endogenous factors (Psycharis, Kallioras, \& Pantazis, 2014). During 2008, the year which marked the beginning of the global financial crisis for all European countries, Greece has experienced the worst economic crisis in its history. The economy was heavily affected after the financial crisis (González-Pernía, Guerrero, Jung, \& Peña-Legazkue, 2018), left with a severe debt crisis (Nelson, Belkin, \& Jackson, 2017), in a spiraling fiscal deficit. During the last decade, to receive economic aid, Greece signed three consecutive agreements. Those agreements were the so-called memorandums of 2010, 2012, and 2015, with three international creditors, the European Central Bank, the European Union, and the IMF (International Monetary Fund), including binding agreements, regarding fiscal adjustment and structural changes, especially in the area of the labor market (Mavridis, 2018). The prolonged and intensifying international economic downturn in recent years was characterized by low inflation rates and high unemployment, combined with labor and fiscal adjustment policies. The strict economic measures started to lift off during 
2019. Those policies led to constant changes, such as wage-setting mechanisms, the abolition of collective agreements, and the promotion of flexible forms of employment and working time arrangements.

Labor is the primary factor of production that directly affects the total cost of production through its components: direct wage costs (nominal wage) and non-wage costs (cash and non-cash benefits, employer's contributions). In international research, there is a wealth of theoretical and empirical evidence on the behavior of medium- and large-sized companies during economic crises in terms of reducing labor costs, especially on stable wage (Babecký, Du Caju, Kosma, Lawless, Messina, \& Rõõm, 2010; Agell \& Lundborg, 2003; Campbell \& Kamlani, 1997). On the other hand, research related to strategic HRM (Human Resources Management) and wage systems during the economic crisis is relatively limited in Greece.

In times of general financial downturn and low firm turnover, a well-designed remuneration system can counter external pressures. Remuneration and reward systems are a tool for more efficient management and company resource allocation (Fey, Björkman, \& Pavlovskaya, 2000; Dowling, Welch, \& Schuler, 1999). According to Aswathappa (2017), the study of the structure of applied remuneration systems is of particular interest, especially in times of recession, as these are related to companies' specific characteristics (e.g., years of activity and workforce composition).

The present study focuses on investigating the aspects of remuneration and reward systems and recording and assessment of changes observed in employment and labor policies from medium- and largesized firms (MLEs) in the region of Attica, Greece, amid a protracted economic downturn.

\section{LITERATURE REVIEW AND HYPOTHESES DEVELOPMENT}

\subsection{Remuneration and reward systems}

In modern literature, remuneration is no longer a cost through which a company acquires the necessary labor to achieve its purposes. It is also an aligning tool for employees associated with the company's strategy to gain a competitive advantage against its competitors (Trevor, 2008).

In the field of Human Resource Management, various definitions of salary and bonus have been suggested in the literature. Kessler (2015) defined remuneration as a "way in which organizations reward their employees for work performed". The remuneration aims to give compensation to employees for their services to the company (Andrews, 1988). Harisson and Liska (2008) pointed out that remuneration is the main reason motivating people to work.

Compensation, as defined by Dessler (2017), includes "all forms of pay or rewards going to em- ployees and arising from their employment". The primary purpose of compensation is the attraction, retention, and motivation of employees (Mondy \& Martocchio, 2016). Compensation has a significant impact on job satisfaction and performance (Siahaan, 2017; Papasotiriou, Skordoulis, Chalikias, \& Sidiropoulos, 2019). Aswathappa (2017) proposed a different definition for remuneration, which is described as the received compensation for employees' contributions to the company. Aswathappa (2017) reported that internal and external factors influence the amount and the type of remuneration. The internal factors include the business strategy, performance appraisal, and employee. The external factors include the labor market, the cost of living, the labor unions, the labor laws, the society, and the economy.

According to Kessler (2015) and Dessler (2017), a remuneration system consists of two main components: direct financial benefits (wages, salaries, incentives, profits, commissions, and bonuses) and indirect financial benefits. Pynes (2013) noted that the remuneration system should be designed to attract, motivate, and retain proficient employees. Stachova, Stacho, and Bartáková (2015) 
concluded that creating a suitable remuneration system depends on the understanding that it will support employees to accomplish both their personal and the company goals. Therefore, the starting point for a remuneration system should be the strategic agenda, mission, and vision of a company (Lawler, 1990). Aswathappa (2017) stated that the remuneration strategy should be in line with the company's overall policy.

Reward systems are used as a tool for more efficient management and disposal of company resources. Maloney and McCarthy (2013) defined a reward system as "the combination of financial and non-financial elements used by an organization to compensate employees for their time, effort and commitment at work". Also, these systems play a major role in the relationship of employer-employee and have a significant impact on the company's finance (Franco-Santos \& GomezMejia, 2015). The following definition of reward management has been given by Armstrong and Taylor (2017): "concerned with the formulation and implementation of strategies and policies in order to reward people fairly, equitably and consistently in accordance with their value to the organization".

Concerning wage reduction, the concept of "downward wage rigidity" is at the heart of Keynes' labor market model. In this model, the notion of downward nominal wage rigidity distinctly affects the existence of unemployment and the rationalization to clear the failure of the labor market (Christofides \& Nearchou, 2015). AvouyiDovi, Fougère, and Gautier (2010) defined downward wage rigidity as "the inability for firms to cut wages in nominal or real terms". Babecký et al. (2010) concluded that workforce composition is related to wage rigidity. Previous studies indicate that the nature and consequences of wage rigidity differ across countries (Messina \& Sanz-de-Galdeano, 2014), while the importance and negative consequences of wage rigidity are increased after an economic recession (Doris, O’Neill, \& Sweetman, 2013). In their review study, Campbell and Kamlani (1997) explain why companies refrain from cutting wages in economic recessions, especially when unemployment is high. They conclude that this is a decision to adjust salaries to meet labor market conditions.

\subsection{Development of hypotheses}

Firm size and age are related to various aspects of the management and organization of companies (Taymaz, 2005; De Kok, Fris, \& Brouwer, 2006). Furthermore, the studies of Van Praag and Versloot (2007) and Brown and Medoff (2003) suggested that firm size and age are positively related to the firm's provided benefits to employees. Keeney and Lawless (2010) concluded that larger firms have more complex pay systems than smaller firms. Babecký, Du Caju, Kosma, Lawless, Messina, and Rõõm (2009) also reported that the size and extent of benefits offered by a company beyond the base wage are related to firm size and workforce composition. Thus, the first null hypothesis that the authors set for this study is:

\section{H1: There is no relationship between the firm size and use of flexible remuneration systems.}

Dias, Marques, and Martins (2013) noted that small firms use labor cost-cutting strategies to a greater extent than larger firms. The adoption of a cost-cutting strategy depends on the firm's characteristics (Montornès \& Suner-Leroy, 2009). Kwapil (2010) observed that firms affected by a crisis chose to reduce non-labor costs as the primary compensatory measure. Keeney and Lawless (2010) found that larger firms have a more complex pay system than smaller ones, giving them greater flexibility regarding the use of non-wage cost-cutting strategies. According to Babecký et al. (2009), firms often prefer more than one cost-reduction strategies. A similar positive correlation was observed with trade unions, which confirms the findings of Kwapil (2010). Babecký et al. (2009) agreed with Keeney and Lawless (2010) that there is a positive correlation between firm size and the use of non-wage methods to reduce labor costs. Hence, the second, third, and fourth hypotheses that have been developed by the authors are:

H2: There is no correlation between the firm size and use of non-wage methods for labor costs reduction.

H3: The impact of economic crisis on a firm is not related to the use of labor cost-cutting strategies. 
H4: There is no correlation between unions and the use of non-wage cost-cutting strategies.

However, a review of international empirical studies showed that even amid the grim times of a protracted recession, which is characterized by high unemployment rates, firms did not adjust wages solely based on labor market conditions (Campbell \& Kamlani, 1997; Agell \& Lundborg 1995, 2003; Agell \& Bennmarker, 2002). The reasons for the rigidity of nominal or real wages varied and are related to companies' specific characteristics (e.g., size, employee composition, trade unions). Summarizing the above, research concluded that companies avoid cutting wages, even in times of economic recession (Agell \& Bennmarker, 2002; Kwapil, 2010). Hence, the fifth hypothesis of this study is:

H5: Firms avoid wage cuts even in times of low turnover.

Fabiani, Kwapil, Rõõm, Galuscak, and Lamo (2010) found that labor market regulations and collective wage agreements may prevent companies from cutting wages. Holden's (2002) theoretical model showed that employment protection legislation (EPL) increases wage rigidity, and the mutual consent of employers and employees is needed for wage cuts in the case of collectively negotiated wage agreements. Since the early 1980s, a series of surveys have been conducted to investigate and understand the mechanisms of wage rigidity (Kaufman, 1984; Blinder \& Choi, 1990; Agell \& Lundborg, 1995; Campbell \& Kamlani, 1997; Agell \& Bennmarker, 2002). As noted by Bewley (1999), the causes of wage rigidity may be related to firm heterogeneity. The reasons for wage rigidity significantly differ across firms, concerning the existence of trade union, firm size (Agell \& Bennmaker, 2006; Dias, Marques, \& Martins, 2013), workforce composition, firm's object of activity, and regional location (Franz \& Pfeiffer, 2006).

Campbell and Kamlani (1997) highlighted that size is related to the mechanism that relates wage cuts with the firm's reputation. In a survey conducted in Sweden, Agell and Lundborg $(1995,2003)$ concluded that smaller companies refused to cut wages because this is negatively associated with recruitment costs, especially in the case of highskilled management staff. Agell and Bennmarker (2002) analyzed the ways that rigidity mechanisms differ between labor market segments. They discovered that these mechanisms differ between small and large firms. In larger companies, the impact on employees' morale and work performance is a critical deterrent to wage reductions. Bewley (2004), summarizing the results of Kaufman (1984), Blinder and Choi (1990), Campbell and Kamlani (1997), Bewley (1999), Levine (1993), and Agell and Lundborg $(1995,2003)$, showed that theories interpreting wage rigidity are more related to morale and loyalty issues than cost issues. Hence, the authors in this research applied the following null hypotheses:

H6: There is no correlation between wage rigidity, labor market legislation, and collective agreements for setting minimum wage levels.

H7: There is no relationship between rigidity mechanisms and firm heterogeneity.

H8: There is no correlation between firm size, sector, and wage cut over the last seven years.

\section{AIM}

The paper aims to examine how the economic crisis affected the structure of employees' remuneration and rewards systems, focusing on medium- and large-sized firms for the region of Attica, Greece.

\section{DATA AND METHODS}

The study adopted the survey method as a research tool (Creswell, 2014) through sampling. Therefore, the research was mainly based on primary data collection. Secondary data were collected from various studies to support the theoretical framework. Primary data were collected using a structured questionnaire, which is based on the studies of Campbell and Kamlani (1997), Agell and Lundborg $(1995,2003)$, and on the questionnaire that was used by Wage Dynamic Network in 2008 (Keeney \& Lawless, 2010). The questions were translated and adapted to the local context. 
The final questionnaire consisted of three sections with sixteen closed-ended questions. This study's sample consisted of medium- and largesized companies in the central Attica region from the ICAP Hellas Group database. The total number of firms that composed the sample was 1,750 medium-sized and 312 large-sized companies. However, only 500 employees from 112 medium-sized and 38 large-sized companies responded to the survey, giving a response rate of about $6.4 \%$ and $12.18 \%$, respectively. The questionnaires were sent via email, and a total of 500 questionnaires were collected. Respondents were executive managers and professionals from economic and human resources departments of the 112 medium-sized and 38 large-sized companies included in the final sample.

The data were analyzed using SPSS 22.0. Descriptive statistical analysis was used to analyze firms' characteristics. The normality of the data was checked by using the Kolmogorov-Smirnov test and the Shapiro-Wilk test. Parametric and non-parametric tests have been used with 5\% statistical significance to test the research hypotheses (Mann-Whitney, Kruskal-Wallis, Chi-square test, One-Way ANOVA, Pearson and Spearman correlation coefficients). Factor Analysis was applied to analyze the correlations between the variables and grouping them into factors. Besides, a Principal Component Analysis method with Varimax Rotation was used. The Varimax method was chosen because it is one of the most popular ways of orthogonal rotation (Sharma, 1996; Hair, Anderson, Tatham, \& Black, 1998). Subsequently, Exploratory Factor Analysis and Reliability Analysis were performed to investigate structural validity, based on Cronbach's alpha statistical measure.

\section{RESULTS}

\subsection{Descriptive statistics}

Table 1 summarizes the general characteristics of the sample firms based on the respondents' answers.

Concerning labor costs reductions according to the descriptive analysis, most firms reported that they use two flexible remuneration systems (33.8\%), while $27.6 \%$ of the firms reported that they use three systems, and $22.6 \%$ use one sys-

Table 1. Demographic characteristics of firms

Source: Own research.

\begin{tabular}{|c|c|c|c|c|c|}
\hline \multirow{3}{*}{ Items } & \multirow{3}{*}{ Variables } & \multicolumn{4}{|c|}{ Firm size (number of employees) } \\
\hline & & \multicolumn{2}{|c|}{ Medium-sized (50-250) } & \multicolumn{2}{|c|}{ Large-sized (Above 250) } \\
\hline & & Frequencies & Percentages & Frequencies & Percentages \\
\hline \multirow{8}{*}{ Sector } & Manufacturing & 63 & $20 \%$ & 5 & $2.7 \%$ \\
\hline & Energy & 29 & $9.21 \%$ & 7 & $3.78 \%$ \\
\hline & Construction & 9 & $2.86 \%$ & 9 & $4.86 \%$ \\
\hline & Information and communications & 32 & $10.16 \%$ & 6 & $3.24 \%$ \\
\hline & Retailing and wholesaling & 86 & $27.3 \%$ & 27 & $14.59 \%$ \\
\hline & Transport and storage & 11 & $3.49 \%$ & 42 & $22.7 \%$ \\
\hline & Services & 76 & $24.13 \%$ & 79 & $42.7 \%$ \\
\hline & Other & 9 & $2.86 \%$ & 10 & $5.41 \%$ \\
\hline \multirow{6}{*}{$\begin{array}{l}\text { Years of } \\
\text { activity }\end{array}$} & $5-17$ & 124 & $39.4 \%$ & 85 & $45.9 \%$ \\
\hline & $17-29$ & 56 & $17.8 \%$ & 32 & $17.3 \%$ \\
\hline & $29-41$ & 114 & $36.2 \%$ & 38 & $20.5 \%$ \\
\hline & $41-53$ & 0 & $0 \%$ & 23 & $12.4 \%$ \\
\hline & $53-65$ & 14 & $4.4 \%$ & 0 & $0 \%$ \\
\hline & $>77$ & 7 & $2.2 \%$ & 7 & $3.8 \%$ \\
\hline \multirow{5}{*}{$\begin{array}{l}\text { Employee } \\
\text { benefits }\end{array}$} & Work interruption program & 73 & $23.2 \%$ & 21 & $11.4 \%$ \\
\hline & $\begin{array}{c}\text { Maternity, paternity, and parental } \\
\text { leave }\end{array}$ & 186 & $59 \%$ & 128 & $69.2 \%$ \\
\hline & Pension plan & 153 & $48.6 \%$ & 80 & $43.2 \%$ \\
\hline & Educational leave & 104 & $33 \%$ & 70 & $37.8 \%$ \\
\hline & Private health insurance program & 235 & $74.6 \%$ & 149 & $80.5 \%$ \\
\hline
\end{tabular}


tem. The remaining $16 \%$ of the firms do not use flexible remuneration systems at all. Concerning the number of strategies to reduce labor costs over the last seven years, firms mostly used almost three different strategies (20\%), followed by one strategy (19.8\%), four strategies (19.4\%), and a lower percentage with no strategy (15.8\%). In multiple response questions concerning the preferred strategies, the strategy that is mostly preferred by firms is the "Recruitment of new employees at a lower wage level than those who voluntarily left" (34.6\%). The other strategies that were selected are "Reduced or eliminated bonus payments" (30.8\%), "Encouraging early retirement to replace high wage employees" (28.8\%), "Reduction or elimination of other nonsalary benefits" (24.6\%), "Never tried to reduce labor costs" (15.8\%), "Never tried to reduce labor costs" (11\%) and "Changes shift assignments or shift premia" (9.6\%). Most firms also reported that their turnover is now lower (45.8\%), followed by "about the same" (21.8\%) and "much lower" (19\%), while "higher" and "much higher" were reported at $11.4 \%$ and $2 \%$, respectively. Also, most respondents (56.2\%) confirmed their firms' participation in an employer organization. Finally, about half of the respondents (50.6\%) confirmed the existence of an employees' union in the company.

Table 2 demonstrates the answers of respondents to a question about the various reasons that retain firms to apply a wage cut.

According to Table 2, the most important reasons not to apply a wage cut are the negative impact on employee's morale and the lack of recognition of the employee's effort.

Table 3 presents the flexible benefits to employees per professional category. As expected, highly qualified employees and management are most likely to receive a bonus element to their remuneration, while low-skilled workers are likely to be reward-

Table 2. Reasons that refrain firms from cutting wages to reduce labor costs

\begin{tabular}{|c|c|c|c|c|c|c|c|}
\hline & & & & & & Sourc & Own researc \\
\hline Items & Not at all & Slightly & Moderately & Very & Extremely & Mean & $\begin{array}{c}\text { Std. } \\
\text { deviation }\end{array}$ \\
\hline $\begin{array}{l}\text { It is impeded by labor regulation/ } \\
\text { collective agreements }\end{array}$ & $18.6 \%$ & $18.4 \%$ & $27.2 \%$ & $15.4 \%$ & $20.4 \%$ & 3.01 & 1.379 \\
\hline $\begin{array}{l}\text { It would have a negative impact on } \\
\text { employees' morale }\end{array}$ & $3.6 \%$ & $12.2 \%$ & $24.6 \%$ & $43.8 \%$ & $15.8 \%$ & 3.56 & 1.012 \\
\hline $\begin{array}{l}\text { It would have a negative impact on } \\
\text { employees' efforts, resulting in less } \\
\text { output }\end{array}$ & $12 \%$ & $6.4 \%$ & $12.2 \%$ & $56.2 \%$ & $13.2 \%$ & 3.52 & 1.168 \\
\hline $\begin{array}{l}\text { It would have a negative impact on } \\
\text { the firm's reputation as an employer }\end{array}$ & $9.4 \%$ & $19.8 \%$ & $28.4 \%$ & $27.4 \%$ & $15 \%$ & 3.19 & 1.190 \\
\hline $\begin{array}{l}\text { It would mean that the best } \\
\text { employees would leave the firm }\end{array}$ & $5 \%$ & $27.4 \%$ & $24 \%$ & $38.4 \%$ & $5.2 \%$ & 3.11 & 1.027 \\
\hline $\begin{array}{l}\text { Denial of permanent employees who } \\
\text { will be replaced to cooperate with } \\
\text { new and low-paid employees }\end{array}$ & $18.6 \%$ & $27.6 \%$ & $30.6 \%$ & $23.2 \%$ & - & 2.58 & 1.040 \\
\hline $\begin{array}{l}\text { A wage cut would increase the } \\
\text { number of employees who quit, } \\
\text { increasing the cost of hiring and } \\
\text { training new workers }\end{array}$ & $10.6 \%$ & $15 \%$ & $34.2 \%$ & $38.4 \%$ & $1.8 \%$ & 3.06 & 3.06 \\
\hline $\begin{array}{l}\text { In presence of a wage cut the most } \\
\text { productive employees might leave } \\
\text { the firm }\end{array}$ & $6.6 \%$ & $12 \%$ & $32 \%$ & $27.4 \%$ & $22 \%$ & 3.46 & 1.152 \\
\hline $\begin{array}{l}\text { It would create difficulties in } \\
\text { attracting new workers }\end{array}$ & $25.8 \%$ & $25.2 \%$ & $19.2 \%$ & $26.8 \%$ & $3 \%$ & 2.56 & 1.217 \\
\hline $\begin{array}{l}\text { Workers dislike unpredictable } \\
\text { reductions in income. They prefer a } \\
\text { stable wage system }\end{array}$ & $10.2 \%$ & $10.2 \%$ & $21.6 \%$ & $40.4 \%$ & $17.6 \%$ & 3.45 & 1.191 \\
\hline $\begin{array}{l}\text { Employees are concerned with how } \\
\text { their wage compares to that of } \\
\text { similar workers in other firms in the } \\
\text { same market }\end{array}$ & $5.4 \%$ & $24 \%$ & $28.8 \%$ & $38.4 \%$ & $3.4 \%$ & 3.10 & .983 \\
\hline
\end{tabular}


Table 3. Flexible benefits to employees per professional category

\begin{tabular}{|c|c|c|c|c|}
\hline Items & $\begin{array}{c}\text { Individual } \\
\text { performance-related } \\
\text { bonus }\end{array}$ & $\begin{array}{l}\text { Group } \\
\text { performance- } \\
\text { related bonus }\end{array}$ & $\begin{array}{l}\text { Employee stock } \\
\text { options }\end{array}$ & $\begin{array}{l}\text { Participation in } \\
\text { profits }\end{array}$ \\
\hline Low-skilled staff & $8 \%$ & $16 \%$ & $20.6 \%$ & - \\
\hline Administrative/clerical staff & $31.4 \%$ & $35.6 \%$ & $21.8 \%$ & - \\
\hline $\begin{array}{l}\text { Technically-qualified workers and } \\
\text { supervisory staff }\end{array}$ & $55.6 \%$ & $33 \%$ & $20.6 \%$ & - \\
\hline $\begin{array}{l}\text { Highly-qualified employees and } \\
\text { management }\end{array}$ & $85 \%$ & $46.2 \%$ & $32.6 \%$ & $6.2 \%$ \\
\hline
\end{tabular}

Table 4. Percentage of employees in a company who have experienced wage cut over the last seven years

\begin{tabular}{|c|c|c|c|c|c|c|c|c|c|c|}
\hline \multirow{2}{*}{ Item } & \multirow{2}{*}{$\frac{\mathbf{N}}{\text { Statistic }}$} & \multirow{2}{*}{ Range } & \multirow{2}{*}{$\begin{array}{c}\text { Min. } \\
\text { Statistic }\end{array}$} & \multirow{2}{*}{$\begin{array}{c}\text { Max. } \\
\text { Statistic }\end{array}$} & \multirow{2}{*}{$\begin{array}{c}\text { Mean } \\
\text { Statistic }\end{array}$} & \multirow{2}{*}{$\begin{array}{c}\text { Std. } \\
\text { deviation }\end{array}$} & \multicolumn{2}{|c|}{ Skewness } & \multicolumn{2}{|c|}{ Kurtosis } \\
\hline & & & & & & & Statistic & $\begin{array}{l}\text { Std. } \\
\text { error }\end{array}$ & Statistic & $\begin{array}{l}\text { Std. } \\
\text { error }\end{array}$ \\
\hline $\begin{array}{l}\text { Percentage of } \\
\text { employees who have } \\
\text { experienced wage cut }\end{array}$ & 500 & 86.00 & 14.00 & 100.00 & 50.7078 & 31.82035 & .556 & .195 & -1.423 & .389 \\
\hline
\end{tabular}

ed with individual and company performance or choose a stock option program. Table 3 illustrates that highly qualified employees receive the highest bonuses in individual and company-related performance bonuses, employee stock options, and profit-sharing when payable. Furthermore, 442 firms (288 medium-sized and 154 large-sized) considered that individual performance-related bonus is a key tool to reward employees, while company-related performance bonus is applied by 291 firms (212 medium-sized and 79 large-sized). Employee stock options is used as a bonus by 163 firms (101 medium-sized and 62 large-sized), while only 31 firms (22 medium-sized and 9 large-sized) apply the profit-sharing only to highly qualified staff.

Based on the respondents' answers, it is more comfortable over the last seven years to reduce labor costs. According to the results presented in Table 4, companies cut employees' wages, on average, to $50.71 \%$ of their personnel (mean: $50.7078 \%$ - std. deviation: 31.82).

Based on the results of Table 5, large-sized firms (53.5\%) have cut wages more than medium-sized firms (41.6\%). Most of the firms that cut wages were in the construction sector. The lowest wage cuts occurred in energy sector (19.4\%), and very few were reported in the retailing and wholesaling sectors (12.4\%).
Table 5. Incidence of wage cuts

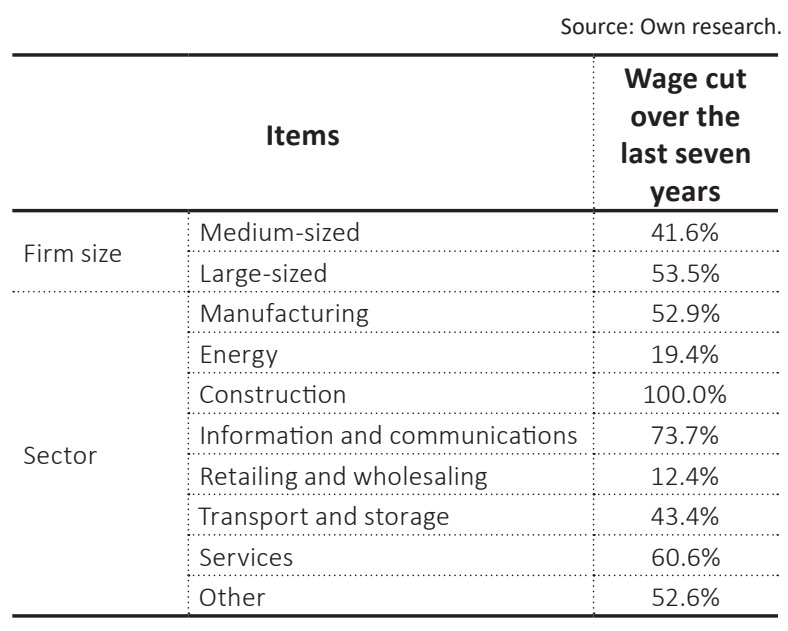

The results of Table 6 indicate that firms prefer to reduce "other costs" to react to an unanticipated slowdown in demand $(\mathrm{M}=3.56, \mathrm{SD}=0.968)$.

Table 7 demonstrates the means and standard deviations of the followed strategies that firms selected to reduce labor costs. It has been found that the most important measure is the "Recruitment of new employees at lower wage level than those who left voluntarily" ( $M=3.44, S D=1.151)$. From this table, the means of the other items were above the default arithmetic mean (2.5), except the item which reported the lowest mean and standard deviation "Changes shift assignments or shift premia” ( $\mathrm{M}=2.42, \mathrm{SD}=1.040)$. 
Table 6. Firms' reaction to an unanticipated slowdown in demand

Source: Own research.

\begin{tabular}{|c|c|c|c|c|c|c|c|}
\hline Items & $\begin{array}{c}\text { Not at } \\
\text { all }\end{array}$ & Slightly & Moderately & Very & Extremely & Mean & $\begin{array}{c}\text { Std. } \\
\text { deviation }\end{array}$ \\
\hline Reduce selling prices & $5.8 \%$ & $23.4 \%$ & $33 \%$ & $29.2 \%$ & $8.6 \%$ & 3.11 & 1.045 \\
\hline Reduce profit margins & - & $28.8 \%$ & $45.8 \%$ & $10.4 \%$ & $15 \%$ & 3.12 & .990 \\
\hline Reduce output & $27.2 \%$ & $21.2 \%$ & $19.2 \%$ & $17.4 \%$ & $15 \%$ & 2.72 & 1.414 \\
\hline Reduce other costs & - & $14 \%$ & $36.4 \%$ & $29.2 \%$ & $20.4 \%$ & 3.56 & .968 \\
\hline
\end{tabular}

Table 7. Descriptive statistics for the strategies that firms select to reduce labor costs

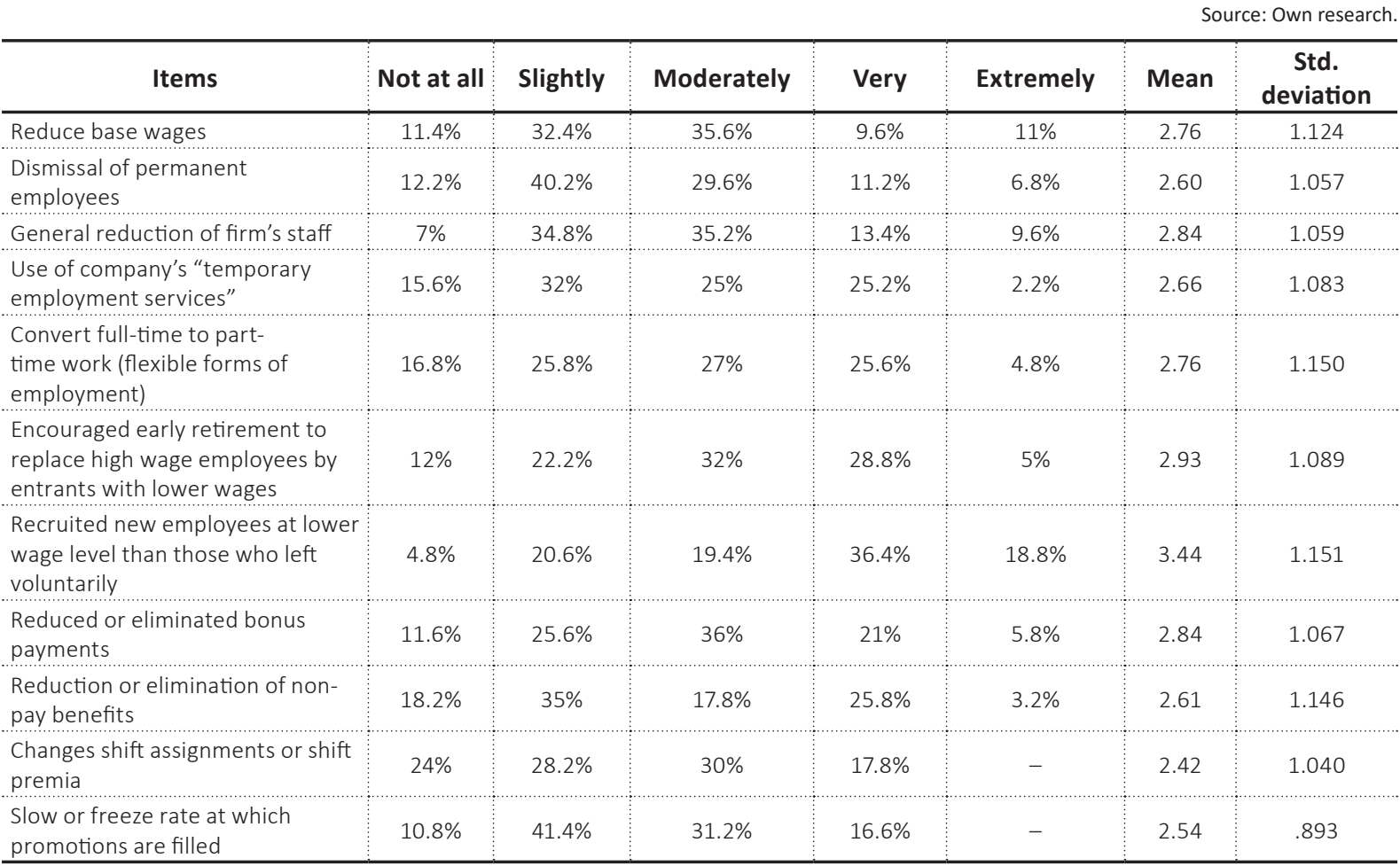

\subsection{Factor analysis}

To test the reliability, Cronbach's alpha test was used for internal consistency, while the results above 0.7 are satisfactory and acceptable (Burns \& Grove, 2001). The Cronbach's Alpha for the first set of questions (11 items) was 0.833 , indicating a high internal consistency. Among the several approaches of factor analysis, the method of Principal Component Analysis was chosen. Tabachnick and Fidell (2013) proposed 0.6 as the minimum value of KMO index. Also, for factor analysis to be appropriate, Bartlett's test is significant when $p<0.05$ (Bartlett, 1950). The KaiserMeyer-Olkin (KMO) measure of sampling adequacy and Bartlett's test were performed for the 11 items (measures for labor costs reduction). As shown in Table 8, the Kaiser-Meyer Olkin meas- ure of sampling adequacy (KMO) was $0.667>0.50$ (Hair et al., 2006), indicating that the data were suitable for factor analysis and Bartlett's test of sphericity was significant, with $p=.000<0.001$ (Field, 2013), showed that Principal Components Analysis (PCA) is appropriate.

Table 8. KMO and Bartlett's test

Source: Own research (SPSS 22)

\begin{tabular}{|c|c|c|}
\hline \multicolumn{2}{|c|}{$\begin{array}{l}\text { Kaiser-Meyer-Olkin measure of sampling } \\
\text { adequacy }\end{array}$} & .667 \\
\hline \multirow{3}{*}{$\begin{array}{l}\text { Bartlett's test of } \\
\text { sphericity }\end{array}$} & Approx. Chi-square & 3126.822 \\
\hline & $d f$ & 55 \\
\hline & Sig. & .000 \\
\hline
\end{tabular}

Four factors (Table 9) with an eigenvalue greater than one, explaining approximately $76.83 \%$ of the variance, were derived from the analysis. The 
Table 9. Factor analysis of the strategies to reduce labor costs

Source: Own research (SPSS 22).

\begin{tabular}{|c|c|c|c|c|}
\hline Variables & Factor 1 & Factor 2 & Factor 3 & Factor 4 \\
\hline \multicolumn{5}{|c|}{ Factor 1: Direct interventions } \\
\hline Reduce base wages & 0.900 & - & - & - \\
\hline Dismissal of permanent employees & 0.839 & - & - & - \\
\hline General reduction of firm's staff & 0.855 & - & - & - \\
\hline Recruited new employees at lower wage level than those who left voluntarily & 0.603 & - & - & - \\
\hline Convert full-time to part-time work (flexible forms of employment) & 0.507 & - & - & - \\
\hline \multicolumn{5}{|l|}{ Factor 2: Flexible strategies } \\
\hline Changes shift assignments or shift premia & - & 0.882 & - & - \\
\hline Slow or freeze rate at which promotions are filled & - & 0.831 & - & - \\
\hline \multicolumn{5}{|c|}{ Factor 3: Supplementary fees } \\
\hline Reduced or eliminated bonus payments & - & - & 0.941 & - \\
\hline Reduction or elimination of non-pay benefits & - & - & 0.793 & - \\
\hline \multicolumn{5}{|c|}{ Factor 4: Additional flexible strategies } \\
\hline Use of company's "temporary employment services" & - & - & - & 0.878 \\
\hline $\begin{array}{l}\text { Encouraged early retirement to replace high wage employees by entrants with } \\
\text { lower wages }\end{array}$ & - & - & - & 0.761 \\
\hline \multicolumn{5}{|c|}{ Total variance explained } \\
\hline Initial eigenvalues (Total) & 4.236 & 1.854 & 1.357 & 1.005 \\
\hline Initial eigenvalues (\% of variance) & 38.51 & 16.85 & 12.33 & 9.13 \\
\hline Initial eigenvalues (cumulative \%) & $38.51 \%$ & $55.36 \%$ & $67.7 \%$ & $76.83 \%$ \\
\hline Reliability Alpha coefficients & 0.846 & 0.854 & 0.816 & 0.617 \\
\hline
\end{tabular}

factor "Direct interventions" has the highest eigenvalue (4.236), representing $38.51 \%$ of the explained variance. The second highest eigenvalue was the "Flexible strategies" factor. This value of 1.854 represented $16.85 \%$ of the explained variance in the sample. The "Supplementary fees" factor had 1.357 eigenvalues, representing $12.34 \%$ of the explained variance followed by the "Additional Flexible Strategies" factor, which had an eigenvalue of 1.005 , representing $9.14 \%$ of the explained variance. Therefore, reliability coefficients (Cronbach's alpha) were calculated for the items of each factor. The reliability coefficients for the 4 factors (strategies) were $0.846,0.854,0.816$, and 0.617 , respectively. The results show that the reliability coefficients for these factors exceeded the recommended level of 0.50 .

Figure 1 shows the scree plot for the first 11 factors. There are four eigenvalues greater than 1 , and the plot levels off after the fourth factor, indicating that four factors should be rotated.

Moreover, KMO index for sample adequacy $(\mathrm{KMO}=0.557>0.50)$ showed that the data of the second set of questions (11 items) were suitable for

Scree plot

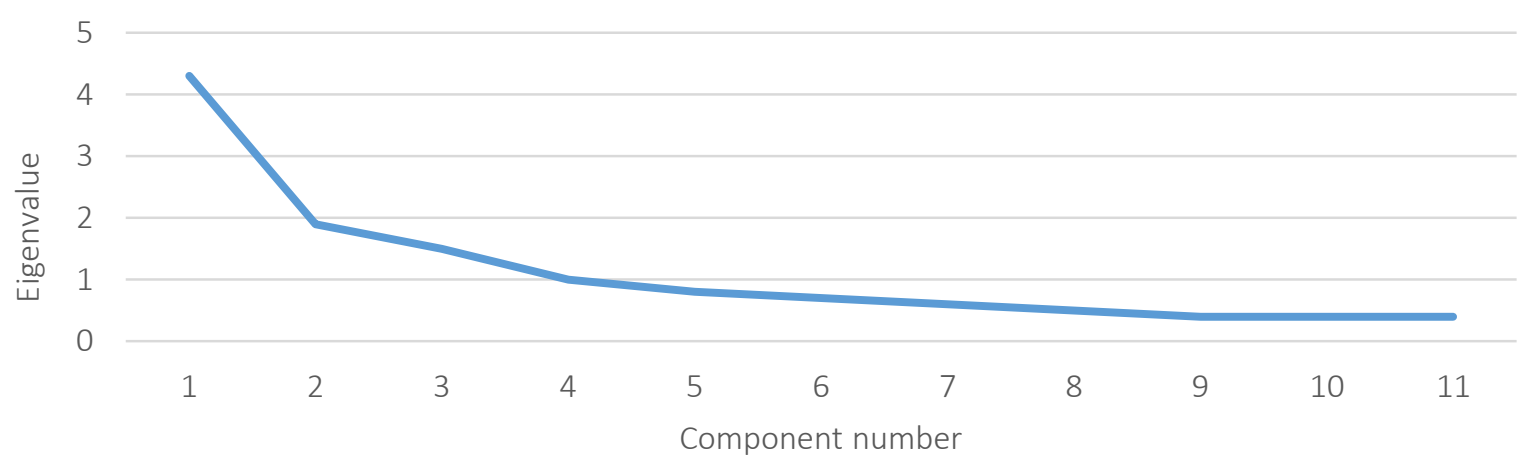

Figure 1. Scree plot 
factor analysis, and the Bartlett's test of sphericity (Bartlett's sign $0.000<0.01$ ) showed that Principal Components Analysis (PCA) is appropriate and one factor was extracted: Internal_Reasons: Employees Reaction.

\subsection{Hypotheses testing}

The non-parametric Mann-Whitney test was applied to test statistical differences between firm size and the use of flexible remuneration systems. The results showed that firms use flexible remuneration systems to a moderate degree $(\mathrm{M}=2.47$, $\mathrm{SD}=.166)$, and there is no difference in the use of flexible remuneration systems between medium- and large-sized companies ( $p=0.288>0.05$ ). Therefore, the first hypothesis (H1) is accepted; thus, there is no statistically significant relationship between firm size and the use of flexible remuneration systems.

To investigate the second hypothesis (H2), Spearman's rho was used to examine the relationship between firm size and use of non-wage methods for labor costs reduction since the examined variables do not follow the normal distribution. According to the results in Table 10, it is found that there is no statistically significant relationship between firm size three of four cost-cutting strategies $(p 1=0.728$ $>0.05 ; p 2=0.104>0.05 ; p 3=0.739>0.05)$. On the other hand, there is a statistically significant positive relationship between the number of employees and the use of flexible-non wage strategies $(p 1=0.002<$ $0.05)$. As the number of employees is bigger, flexible strategies are often selected. Hence, the second hypothesis $(H 2)$ is partially accepted.

To test $H 3$, whether significant differences exist between a firm's turnover and the number of strategies that firms used to reduce labor costs over the last seven years, the Kruskal-Wallis non-parametric test was applied. The results showed statistically significant difference among the examined variables $(p=0.001>0.000 ; x 2(4)=123.327)$; thus, the third hypothesis is rejected. Therefore, there is a relationship between the economic crisis and the use of labor cost-cutting strategies.

To test $H 4$ the Mann-Whitney U-test was used to verify the existence of a statistical relationship between unions and the usage of non-wage cost-cutting strategies. As presented in Table 11, there is a statistically significant difference between unions and four nonwage cost-cutting strategies $(p 1, p 2, p 3, p 4=0.000<$ $0.05)$. Hence, the fourth hypothesis is rejected.

Concerning H5, Pearson correlation coefficient test was used to assess the correlation between firm's turnover and wage cut. A statistically significant correlation existed between wage cuts over the last seven years and firms reporting turnover lower than in the previous year $(p=0.000<0.05 ; x 2(4)=112.163)$. Thus, the fifth hypothesis is rejected. It is concluded that firms cut wages, and it is based on the effects of economic crisis on firm's turnover.

Concerning H6, Pearson correlation coefficient test was used to evaluate the relationship between wage rigidity, labor market legislation, and collective agreements. According to the results $(p=0.05>0.000$; $x 2(4)=78.989)$, there is a statistically significant relationship between the aforementioned variables. The same correlation results are obtained between wage rigidity and the presence of trade unions and their involvement in wage-setting agreements $(p=0.000<$ $0.05 ; x 2(1)=72.309)$.

Furthermore, Analysis of Variance (ANOVA) F-test was applied to test $H 7$ about the correlation between the new factor that measures the extent

Table 10. Correlations between firm size and use of non-wage methods

Source: Own research (SPSS 22).

\begin{tabular}{|c|c|c|c|c|c|c|c|}
\hline \multicolumn{3}{|c|}{ Correlations } & \multirow{2}{*}{$\begin{array}{c}\begin{array}{c}\text { Number of } \\
\text { employees }\end{array} \\
1.000\end{array}$} & \multirow{2}{*}{$\begin{array}{c}\text { Strategy_1: } \\
\text { Immediate } \\
\text { interventions } \\
-.016\end{array}$} & \multirow{2}{*}{$\begin{array}{l}\begin{array}{c}\text { Strategy_2: } \\
\text { Flexible }\end{array} \\
\text { strategies_1 } \\
.073\end{array}$} & \multirow{2}{*}{$\begin{array}{c}\begin{array}{c}\text { Strategy_3: } \\
\text { Complementary } \\
\text { remunerations }\end{array} \\
.015\end{array}$} & \multirow{2}{*}{$\begin{array}{c}\begin{array}{c}\text { Strategy_4: } \\
\text { Flexible } \\
\text { strategies_2 }\end{array} \\
.139^{* *}\end{array}$} \\
\hline \multirow{3}{*}{$\begin{array}{l}\text { Spearman's } \\
\text { rho }\end{array}$} & \multirow{3}{*}{$\begin{array}{l}\text { Number of } \\
\text { employees }\end{array}$} & $\begin{array}{l}\text { Correlation } \\
\text { coefficient }\end{array}$ & & & & & \\
\hline & & Sig. (2-tailed) & ... & .728 & .104 & .739 & .002 \\
\hline & & $\mathrm{N}$ & 500 & 500 & 500 & 500 & 500 \\
\hline
\end{tabular}

Note: **. Correlation is significant at the 0.01 level (2-tailed). 
Table 11. Test statistics ${ }^{a}$ for the presence of unions and non-wage cost-cutting strategies

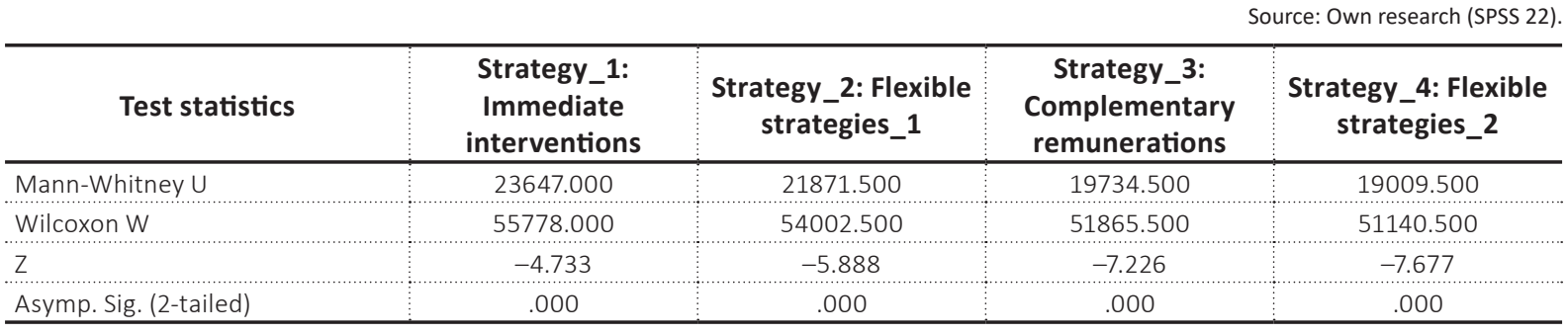

Note: a. Grouping variable: union.

Table 12. ANOVA results

Source: Own research (SPSS 22).

\begin{tabular}{|c|c|c|c|c|c|}
\hline \multicolumn{6}{|c|}{ Internal_Reasons: Employees' reaction } \\
\hline & Sum of squares & df & Mean square & $\mathbf{F}$ & Sig. \\
\hline Between groups & 36.695 & 7 & 5.242 & 10.432 & .000 \\
\hline Within groups & 247.228 & 492 & .502 & - & - \\
\hline Total & 283.923 & 499 & - & - & - \\
\hline
\end{tabular}

to which employees' morale, performance, and engagement (Internal_Reasons) will be affected after a wage cut and the variables of firm's sector, size, and workforce composition. Table 12 and Figure 2 present the output of the ANOVA analysis to examine if there is a statistically significant difference between a firm's sector and the new factor (Internal_Reasons). The results indicate that the significance value is $p=0.000(F=10.432)$, which is below 0.05; therefore, there is a statistically significant difference between these variables.

Spearman's correlation coefficient results (rho $=-0.255 ; p=0.000<0.05)$ showed a low negative significant correlation between firm size (based on the number of employees) and new fac- tor (Internal_Reasons). Also, similar results were observed in Table 13, as Spearman's correlation coefficient results showed a low statistical significant correlation ( $\mathrm{rhol}=-0.112-p 1=0.013$; rho $2=-0.326-p 2=0.000 ;$ rho3 $=-0.181-p 3=$ 0.000 ; rho $4=-0.193-p 4=0.000$ ) between employees who are distributed across four occupational groups and new factor (Internal_Reasons). Summarizing the results above, the seventh hypothesis is partially accepted.

Finally, $\mathrm{HO}$ is rejected showing that there is a statistical significant relationship between firm size, sector $(p=0.000<0.05 ; x 2(7)=109.649)$, and wage cut $(p=0.010<0.05 ; x 2(1)=6.674)$ over the years of the economic crisis.

Source: Own research (SPSS 22).

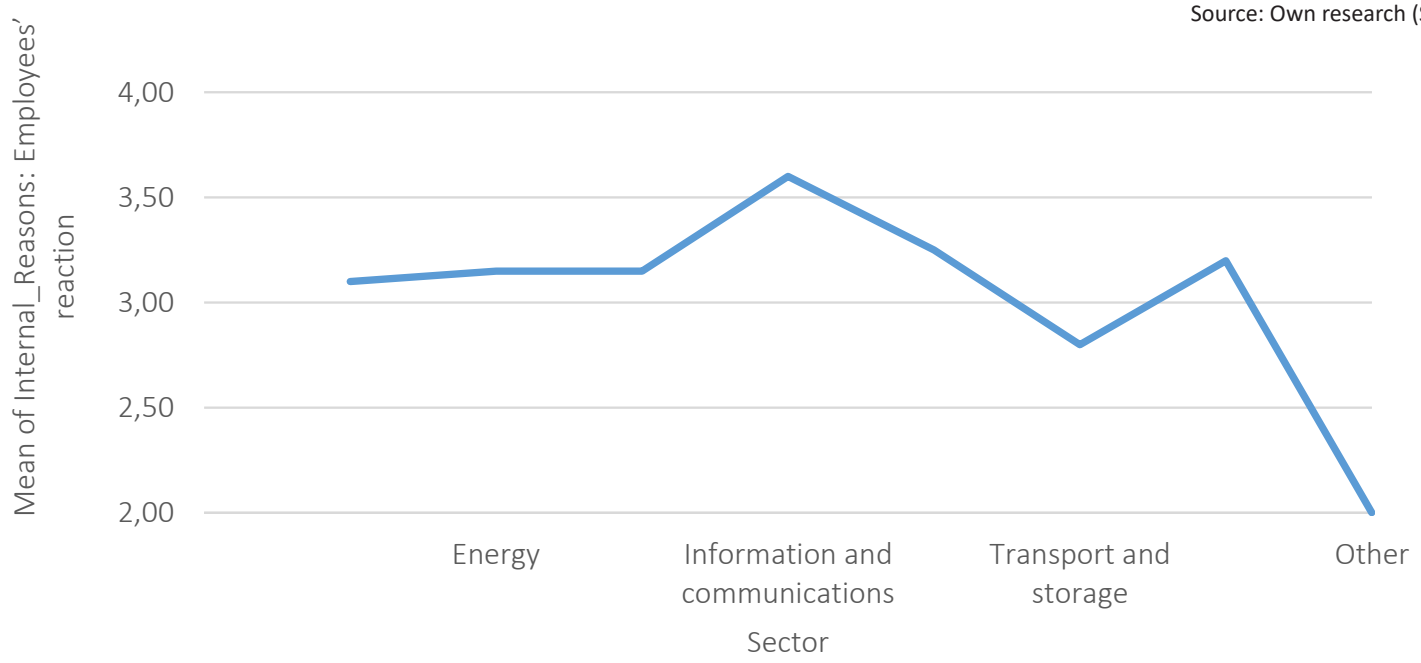

Figure 2. ANOVA means plot 
Table 13. Correlations between firm size and internal reasons

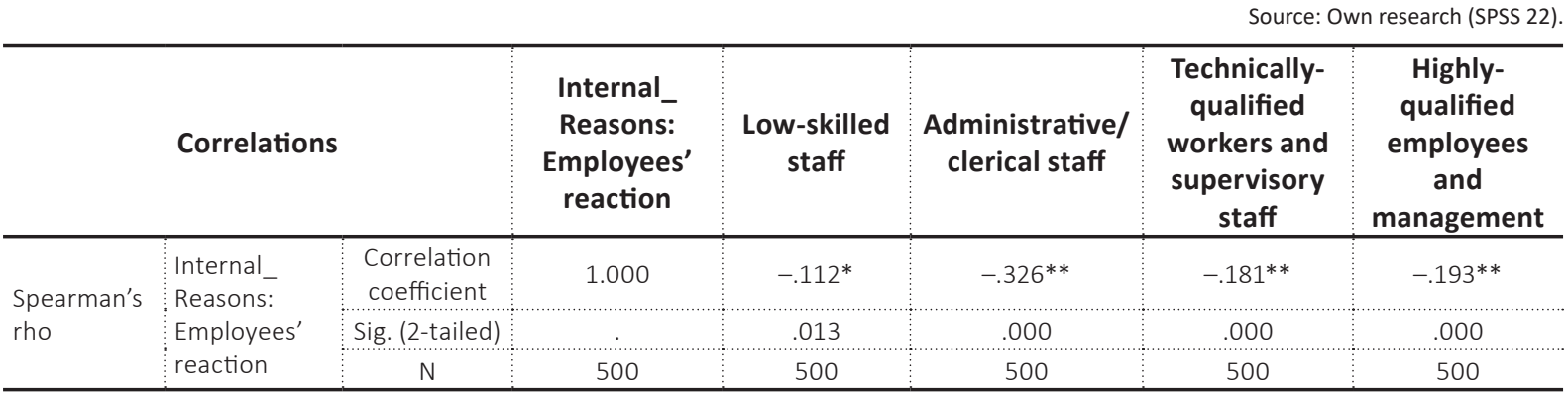

Note: *. Correlation is significant at the 0.05 level (2-tailed); ${ }^{* *}$. Correlation is significant at the 0.01 level (2-tailed).

\section{DISCUSSION}

In times of prolonged economic downturn, the study of remuneration systems presents a particular interest, reflecting the overall business strategy and culture and the ability of companies to face economic and social shocks (Babecký et al., 2009). It is undoubtedly true that remuneration systems play a critical role for company's organizational design (Lawler, 1995). Data analysis in this study between the impact of the economic downturn on firm's performance and the use of strategies to reduce non-wage costs revealed a statistically significant relationship. Firms with low turnover during the economic crisis made wider use of the methods and strategies to reduce labor costs. Keeney and Lawless (2010) and de Kok (2012) suggest a positive correlation between firm size and flexible wage components. This finding is in line with the results of Kwapil (2010), Keeney and Lawless (2010) who reported that companies with active trade unions can use non-wage labor cost reduction methods. It has also been found that these unions have the power to prevent staff reduction and wage cuts.

The respondents reported that during the last seven years of the crisis, most of the firms have used at least one strategy to reduce their costs. These results are in line with the empirical findings of Martins (2011) and Babecký et al. (2009). It is also noted that there is a difference between firm's employees across the occupational groups. This result is in line with Keeney and Lawless (2010) findings, according to which administrative employees and technically qualified staff can receive a performance-related bonus. Furthermore, the method of using outsourcing human resources firms for employee assignment is a way to reduce labor costs.
The companies benefit from such methods from the lower administrative costs since employees do not belong to them (e.g., insurance contributions, money cost, tax on employees' wages). Moreover, cutting an employee's wage based on performance is an equally satisfactory and "easy" solution since there is no legal limitation to reduce these benefits. The findings of this research about the development of wage rigidity are consistent with Bewley (2004).

Furthermore, it was concluded that there is no statistically significant relationship between firm size and use of non-wage methods, a result which is possibly related to the composition of the sample (limited number of large-sized companies). The results also showed a statistically significant correlation between firm size, sector, and wage cut over the last seven years. The results showed a statistically significant correlation between firm size, sector, and wage cut over the last seven years. The findings revealed a correlation between firm's turnover and wage cuts and a significant relationship between wage rigidity, labor market legislation, and collective agreements. Greek firms consider that labor regulation is one of the factors that prevent wage cuts. These conclusions are consistent with other studies (Fabiani et al., 2010; Kwapil, 2010; Agell \& Bennmarker, 2002; Franz \& Pfeiffer, 2006).

In the same line, the adverse selection model explains the wage rigidity to a great degree since employees who left voluntarily and the negative impact on the firm's reputation have received a high acceptance from firms. That is coincident with the conclusions of previous studies on the rigidity (Kaufman, 1984; Blinder \& Choi, 1990; Campbell \& Kamlani, 1997) 


\section{CONCLUSION}

According to the results of the research, the firms of the sample have been significantly affected by the crisis since most of the respondents (64.8\%) reported a turnover reduction in their firms. Medium- and large-sized firms in Greece applied complex remuneration systems, with a range of rewards beyond the base wage. $88.4 \%$ of firms consider individual performance-related bonus the key tool for rewarding employees. Furthermore, company performance-related bonus is applied by $58.2 \%$ of firms, while the employee stock options and participation in profits is applied by $32.6 \%$ and $6.2 \%$ of firms, respectively.

Besides, it was found that there is no statistically significant relationship between firm size and the extent to which firms apply flexible wage policies (e.g., bonuses, benefits). Regarding the extra benefits, most firms (98\%) provide their employees with at least one non-wage benefit. The main non-wage offered benefits were private health insurance programs $(76.8 \%)$ and maternity, paternity, and parental work permits (62.8\%). Concerning firm's reaction to an unanticipated slowdown in demand, it was concluded that they would reduce external costs (86\%), profit margins $(71.2 \%)$, and selling prices (70.8\%). Among the most popular strategies to reduce labor costs, firms preferred the use of company's "temporary employment services" (38.2\%), recruiting new employees at a lower salary than those who left voluntarily (34.6\%), reducing basic wage (33.8\%), and reducing or eliminating bonuses (30.8\%). Besides, more than $90.4 \%$ of the respondents considered that it is easier to adjust wages to reduce labor costs over the last seven years, as labor is cheaper and more employees are available on the market (56.4\%), and employment protection has become less tight (31.4\%). Also, only $46 \%$ of firms cut wages during the economic crisis; this measure was applied to $50.71 \%$ of their employees.

Summing up the results, it can be concluded that most firms in the sample experienced reduced turnover during the period 2009-2019 of the economic recession in Greece. On the other hand, there is a denial or reluctance of firms to cut employees' wages as a result of their belief that this decision will harm employees' efforts, resulting in less output and quality of their work and a reduction of their morale. The companies that participated in the survey agreed that cutting wages comes in contrast with the "informal" agreement between firms and employees to maintain a stable wage system, even in case of an undesirable turnover. Therefore, cutting wages should be the last choice by firms since remuneration is a source for satisfying, engaging, and attracting employees.

\section{AUTHOR CONTRIBUTIONS}

Conceptualization: Evangelia Triantafyllou, Miltiadis Chalikias.

Data curation: Georgios Sidiropoulos, Stamatios Ntanos.

Formal analysis: Georgios Sidiropoulos, Evangelia Triantafyllou.

Investigation: Grigorios L. Kyriakopoulos, Stamatios Ntanos.

Methodology: Stamatios Ntanos, Georgios Sidiropoulos.

Project administration: Stamatios Ntanos.

Supervision: Miltiadis Chalikias, Grigorios L. Kyriakopoulos.

Validation: Grigorios L. Kyriakopoulos, Miltiadis Chalikias.

Visualization: Evangelia Triantafyllou, Miltiadis Chalikias.

Writing - original draft: Evangelia Triantafyllou, Georgios Sidiropoulos.

Writing - review \& editing: Stamatios Ntanos, Grigorios L. Kyriakopoulos. 


\section{REFERENCES}

1. Agell, J., \& Bennmarker, H. (2002) Wage policy and endogenous wage rigidity: a representative view from the inside (CESifo Working Paper No. 751). Retrieved from https:// www.ifo.de/DocDL/751.pdf

2. Agell, J., \& Bennmarker, H. (2006). Wage incentives and wage rigidity: A representative view from within. Labor Economics, 14(3), 347-369. https://doi.org/10.1016/j. labeco.2006.04.002

3. Agell, J., \& Lundborg, P. (1995). Theories of pay and unemployment: survey evidence from Swedish manufacturing firms. Scandinavian Journal of Economics, 97(2), 295-307. https://doi. org/10.2307/3440530

4. Agell, J., \& Lundborg, P. (2003). Survey Evidence on Wage Rigidity and Unemployment: Sweden in the 1990s. Scandinavian Journal of Economics, 105(1), 15-29. Retrieved from https://www.jstor. org/stable/3440918

5. Akerlof, G. A., Dickens, W. T., \& Perry, W. L. (1996). The macroeconomics of low inflation. Brookings Papers on Economic Activity, 27(1), 1-75. Retrieved from https:// www.brookings.edu/wp-content/ uploads/1996/01/1996a_bpea_akerlof_dickens_perry_gordon_ mankiw.pdf

6. Andrews, Y. (1988). The personnel function. Pretoria: HAUM. Retrieved from https://www.worldcat. org/title/personnel-function/ oclc/122330662

7. Armstrong, M., \& Taylor, S. (2017). Armstrong's Handbook of Human Resource Management Practice (14th ed.). Kogan Page Publishers.

8. Aswathappa, K. (2017). Human Resource Management: Text and Cases (8th ed.) McGraw-Hill Education.

9. Avouyi-Dovi, S., Fougere, D., \& Gautier, E. (2010). Wage rigidity, collective bargaining and the minimum wage: evidence from French agreement data (Working paper No. 287). Banque de France. http://dx.doi.org/10.2139/ ssrn. 1653890
10. Babecký, J., Du Caju, P., Kosma, T., Lawless, M., Messina, J., \& Rõõm, T. (2009). The Margins of Labor Cost Adjustment: Survey Evidence from European Firms (Working Paper Series No. 1106). European Central Bank. Retrieved from http://www.oecd.org/els/ emp/46223214.pdf

11. Babecký, J., Du Caju, P., Kosma, T., Lawless, M., Messina, J., \& Rõõm, T. (2010). Downward Nominal and Real Wage Rigidity: Survey Evidence from European Firms. The Scandinavian Journal of Economics, 112(4), 884-910. https://doi.org/10.1111/j.14679442.2010.01624.x

12. Bartlett, M. S. (1950). Tests of Significance in Factor Analysis. British Journal of Statistical Psychology, 3(4), 77-85. https:// doi.org/10.1111/j.2044-8317.1950. tb00285.x

13. Bewley, T. F. (1999). Why Wages Don't Fall During a Recession. Cambridge, MA: Harvard University Press.

14. Bewley, T. F. (2004). Fairness, Reciprocity, and Wage Rigidity (IZA Discussion Paper No. 1137). Institute for the Study of Labor (IZA), Bonn. Retrieved from https://www.econstor.eu/bitstream/10419/20374/1/dp1137.pdf

15. Blinder, A. S., \& Choi, D. H. (1990). A Shred of Evidence on Theories of Wage Stickiness. The Quarterly Journal of Economics, 105(4), 1003-1015. Retrieved from https://www.jstor.org/ stable/2937882

16. Brown, C., \& Medoff, J. L. (2003). Firm age and wages. Journal of Labor Economics, 21(3), 677-697. https://doi.org/10.1086/374963

17. Bullard, J., \& Keating, J. W. (1995). The long-run relationship between inflation and output in postwar economies. Journal of Monetary Economics, 36(3), 477-496. https://doi.org/10.1016/03043932(95)01227-3

18. Burns, N., \& Grove, S. K. (2001). The practice of Nursing Research. Conduct, critique and utilization (4th ed.). WB Saunders Company, Philadelphia, PA.

19. Campbell, C., \& Kamlani, S. K. (1997). The Reasons for Wage Rigidity: Evidence from a Survey of Firms. The Quarterly Journal of Economics, 112(3), 759-789. https://doi. org/10.1162/003355397555343

20. Christofides, N. L., \& Nearchou, P. (2015). Patterns of nominal and real wage rigidity. In $S$. W. Polachek \& K. Tatsiramos (Eds.), Jobs, Training, and Worker Well-being (pp. 301-337). https://doi.org/10.1108/S01479121(2010)0000030013

21. Creswell, J. W. (2014). Research Design: Qualitative, Quantitative and Mixed Methods Approaches. Sage, Los Angeles. Retrieved from http://englishlangkan. com/produk/E\%20Book\%20 Research\%20Design\%20Cressweell\%202014.pdf

22. De Kok, J. M. P. (2012). Do firm size and firm age affect employee remuneration in Dutch SMEs? (EIM Research Report No. H201210). Amsterdam Center of Entrepreneurship. Retrieved from https://econpapers.repec.org/ paper/eimpapers/h201210.htm

23. De Kok, J. M. P., Fris, P., \& Brouwer, P. (2006). On the relationship between firm age and productivity growth (EIM Research Report No. H200617). Zoetermeer: EIM. Retrieved from https://econpapers.repec.org/paper/eimpapers/ h200617.htm

24. Dessler, G. (2017). Human Resource Management (15th ed.). Pearson Education Limited.

25. Dias, A. D., Marques, C. R., \& Martins, F. (2013). Wage rigidity and employment adjustment at the firm level: Evidence from survey data. Labor Economics, 23, 40-49. https://doi.org/10.1016/j. labeco.2013.02.001

26. Doris, A., O’Neill, D., \& Sweetman O. (2013). Wage flexibility and the great recession: The Response of the Irish labor market (IZA Discussion Paper No. 7787). The Institute for 
the Study of Labor. Retrieved from http://ftp.iza.org/dp7787.pdf

27. Dowling, P. J., Welch, D. E., \& Schuler, R. S. (1999). International Human Resource Management: Managing People in an International Context (3rd ed.). Cincinnati: South Western College.

28. Fabiani, S., Kwapil, C., Rõõm, T., Galuscak, K., \& Lamo, A. (2010). Wage Rigidities and Labor Market Adjustment in Europe. Journal of the European Economic Association, 8(2-3), 497-505. https://doi. org/10.1111/j.1542-4774.2010. tb00520.x

29. Fey, C. F., Björkman, I., \& Pavlovskaya, A. (2000). The Effect of Human Resource Management Practices on Firm Performance in Russia. International Human Resource Management, 11(1), 1-18. https://doi. org/10.1080/095851900339963

30. Field, A. (2013). Discovering Statistics Using IBM SPSS Statistics (4th ed.). London: SAGE Publications Ltd.

31. Franco-Santos, M., \& GomezMejia, L. (2015). Reward Systems. In Wiley Encyclopedia of Management. https://doi. org/10.1002/9781118785317. weom 050102

32. González-Pernía, L. J., Guerrero, M., Jung, A., \& Peña-Legazkue (2018). Economic recession shake-out and entrepreneurship: Evidence from Spain. $B R Q$ Business Research Quarterly, 21(3), 153-167. https://doi.org/10.1016/j. brq.2018.06.001

33. Hair, J. F., Black, B., Babin, B., Anderson, R. E., \& Tatham, R. L. (2006). Multivariate Data Analysis (6th ed.). New Jersey: Prentice Hall.

34. Hanes, C. (2000). Nominal wage rigidity and industry characteristics in the downturns of 1893, 1929, and 1981. American Economic Review, 90(5), 1432-1446. https:// doi.org/10.1257/aer.90.5.1432

35. Harrison, D. A., \& Liska, Z. (2008). Promoting Regular Exercise Occupational Fitness Programme. Journal of Personnel Psychology, 5(5), 27-45.
36. Holden, S. (2002). The costs of price stability - downward nominal wage rigidity in Europe (NBER Working Paper No. 8865). Retrieved from https://www.nber. org/papers/w8865.pdf

37. Keeney, M., \& Lawless, M. (2010). Wage Setting and Wage Flexibility in Ireland: Results from a FirmLevel Survey (Working Paper No. 1181). European Central Bank. Retrieved from https://www. ecb.europa.eu/pub/pdf/scpwps/ ecbwp1181.pdf

38. Kessler, I. (2015). Remuneration Systems. In S. Bach \& M R. Edwards (Eds.), Managing Human Resources: Human Resource Management in Transition (Chapter 12). https://doi. org/10.1002/9781119208235.ch12

39. Kwapil, C. (2010). Firms' Reactions to the Crisis and their Consequences for the Labor Market. Results of a Company Survey conducted in Austria (Working Paper No. 1274). European Central Bank. Retrieved from https://www.ecb.europa.eu/ pub/pdf/scpwps/ecbwp1274.pdf

40. Lawler, E. E. (1990). Strategic pay: Aligning organizational strategies and pay systems. San Francisco, CA, US: Jossey-Bass. Retrieved from https://www.wiley.com/enus/Strategic+Pay\%3A+Aligning+ Organizational + Strategies + and $+\mathrm{P}$ ay+Systems-p-9781555422622

41. Lawler, E. E. (1995). The New Pay: A Strategic Approach. Compensation \& Benefits Review, 27(4), 14-22. https://doi. org/10.1177/088636879502700404

42. Levine, D. I. (1993). Fairness, Markets, and Ability to Pay: Evidence from Compensation Executives. American Economic Review, 83(5), 1241-1259. Retrieved from https:// www.jstor.org/stable/2117559

43. Maloney, M., \& McCarthy, A. (2013). Managing Rewards. In R. Carbery \& C. Cross (Eds.), Human Resource Management: an Introduction. UK: Palgrave Macmillan.

44. Martins, F. (2011). Price and wage setting in Portugal: learning by asking (Working Paper Series No. 1314). European Central
Bank. Retrieved from https://www. ecb.europa.eu/pub/pdf/scpwps/ ecbwp1314.pdf

45. Mavridis, S. (2018). Greece's Economic and Social Transformation 2008-2017. Social Sciences, 7(1), 9. https://doi.org/10.3390/ socsci7010009

46. Messina, J., \& Sanz-de-Galdeano, A. (2014). Wage Rigidity and Disinflation in Emerging Countries. American Economic Journal: Macroeconomics, 6(1), 102-133. Retrieved from http://www.jstor. org/stable/43189572.

47. Mondy, R. W., \& Martocchio, J. J. (2016). Human Resource Management (14th ed.). Pearson New International Edition.

48. Montornès, J., \& Sauner-Leroy, J. B. (2009). Wage-setting behavior in France. Additional Evidence from an Ad-Hoc survey (Working Paper No. 1102). European Central Bank. Retrieved from https://www. ecb.europa.eu/pub/pdf/scpwps/ ecbwp1102.pdf

49. Nelson, R., Belkin, P., \& Jackson, J. (2017). The Greek debt crisis: Overview and implications for the United States (CRS Report). Congressional Research Service. Retrieved from https://fas.org/sgp/crs/row/R44155. pdf

50. Papasotiriou, E., Sidiropoulos, G., Ntanos, S., Chalikias, M., \& Skordoulis, M. (2018). The relationship between professional burnout and satisfaction: A case study for physical education teachers in a Greek urban area. Serbian Journal of Management, 13(2), 353-363. https:// doi.org/10.5937/sjm13-15801

51. Psycharis, Y., Kallioras, D., \& Pantazis, P. (2014). Economic crisis and regional resilience in Greece. Regional Science Policy \& Practice, 6(2), 121-141. https://doi. org/10.1111/rsp3.12032

52. Pynes, E. J. (2013). Human Resources Management for Public and Nonprofit Organizations: $A$ Strategic Approach (4th ed.). San Francisco, CA: Jossey-Bass, John Wiley \& Sons.

53. Shapiro, C., \& Stiglitz, J. E. (1984). Equilibrium Unemployment as a Worker Discipline Device. 
American Economic Review, 74(3), 433-444. Retrieved from http:// www.jstor.org/stable/1804018

54. Sharma, S. (1996). Applied Multivariate Techniques. New York: Willey.

55. Siahaan, E. (2017). The role of compensation: case of female workers. Polish Journal of Management Studies, 15(1), 197-205. https://doi.org/10.17512/ pjms.2017.15.1.19

56. Stachova, K., Stacho, Z., \& Bartáková, G. (2015). Influencing organisational culture by means of employee remuneration. Busi ness: Theory and Practice, 16(3),
264-270. https://doi.org/10.3846/ btp.2015.492

57. Tabachnick, B. G., \& Fidell, L. S. (2001). Using Multivariate Statistics (6th ed.). Pearson New International Edition.

58. Taymaz, E. (2005). Are small firms really less productive? Small Business Economics, 25(5), 429-445. https://doi.org/10.1007/s11187004-6492-x

59. Trevor, J. (2008). Can Compensation be Strategic? A Review of Compensation Management Practice in Leading Multinational Firms (Working Paper Series 03/2008). University of Cambridge. Re- trieved from https://www.jbs.cam. ac.uk/fileadmin/user_upload/research/workingpapers/wp0803.pdf

60. Van Praag, C. M., \& Versloot, P. H. (2007). What is the value of entrepreneurship? A review of recent literature. Small Business Economics, 29, 351-382. https://doi. org/10.1007/s11187-007-9074-X

61. Wolfang, F., \& Friedhelm, P. (2006). Reasons for wage rigidity in Germany. Labor - Review of Labor Economics and Industrial Relations, 20(2), 255-284. https://doi.org/10.1111/j.14679914.2006.00345.x 